\title{
Biliary Anastomotic Stricture after Surgical Management of Mirizzi Syndrome: Treated with Long-term Percutaneous Transhepatic Biliary Drainage
}

\author{
Hwaseong Ryu ${ }^{1}$, Jin Hyeok Kim¹, Ung Bae Jeon¹, Joo Yeon Jang ${ }^{1}$, Tae Un Kim¹, Jeong A Yeom¹, Chankue Park ${ }^{1}$, \\ Kwang Ho Yang ${ }^{2}$ \\ ${ }^{1}$ Department of Radiology, ${ }^{2}$ Division of Hepato-Biliary-Pancreatic Surgery and Transplantation, Department of Surgery, Pusan National University \\ Yangsan Hospital, Yangsan, Korea
}

Mirizzi syndrome (MS) is a rare complication of cholecystolithiasis that is characterized by obstruction of the common hepatic duct due to mechanical compression by impacted stones in the neck of the gallbladder or the cystic duct. Treatment of MS is surgical, and operative procedure would vary depending on its classification type. Biliary stricture after surgical treatment of MS is an unusual complication and endoscopic approach is not possible for patients who have undergone bilioenteric anastomosis. We report a case of a 60-year-old patient with biliary anastomotic stricture after surgical management of MS who was successfully treated with long-term percutaneous transhepatic biliary drainage.

Korean J Pancreas Biliary Tract 2018;23(3):134-138

Keywords: Mirizzi syndrome, Cholecystectomy, Choledochostomy, Postoperative complications, Radiology, Interventional

\author{
Received May 4.2018 \\ Revised Jul. 2, 2018 \\ Accepted Jul. 5, 2018
}

Corresponding author : Jin Hyeok Kim

Department of Radiology, Pusan National University

Yangsan Hospital, 20 Geumo-ro, Mulgeum-eup,

Yangsan 50612, Korea

Tel. +82-55-360-1840 Fax. +82-55-360-1848

E-mail; romario11@hananet.net

\section{INTRODUCTION}

Mirizzi syndrome (MS) is a rare complication of chronic gallstone disease that is characterized by narrowing of the common bile duct (CBD) combined with various grade of inflammation, due to mechanical compression by impacted gallstones or cystic duct stones. ${ }^{1}$ The incidence of MS in patients undergoing cholecystectomy is approximately 0.7 -
$1.8 \%{ }^{2}$ MS is classified according to external compression on CBD (type I), presence of cholecystobiliary fistula (type II-IV), and formation of cholecystoenteric fistula (type V). ${ }^{3}$ Surgical treatment is mainstay for MS and various surgical procedures were suggested depending on the classification type of MS. ${ }^{4-6}$ However, surgical treatment is sometimes challenging due to missed preoperative diagnosis, distortion of the anatomy of biliary tract and fistula formation caused 
by longstanding inflammation, and risk of bile duct injury.

This report describes a case of a patient with biliary anastomotic stricture after surgical management of MS, who was successfully treated with long-term percutaneous transhepatic biliary drainage (PTBD).

\section{CASE}

A 60-year-old male patient presented with abdominal discomfort visited our hospital. Initial vital signs were within normal ranges. Multiple cystic duct stones were detected on abdominal computed tomography (CT) images. Dilatation of proximal CBD and intrahepatic bile ducts (IHDs), and mild wall thickening with enhancement of proximal CBD and gallbladder (GB) were also noted (Fig. 1A, B). Total bilirubin and high sensitivity $\mathrm{C}$-reactive protein levels of the patient were $1.5 \mathrm{mg} / \mathrm{dL}$ and $4.37 \mathrm{mg} / \mathrm{dL}$, respectively. MS with cholangitis was considered clinically, but cholangiocarcinoma involving the CBD or GB cancer couldn't be excluded on CT study. For further evaluation, endoscopic retrograde cholangiopancreatography was performed, and a cholangiogram revealed relatively smooth narrowing of the
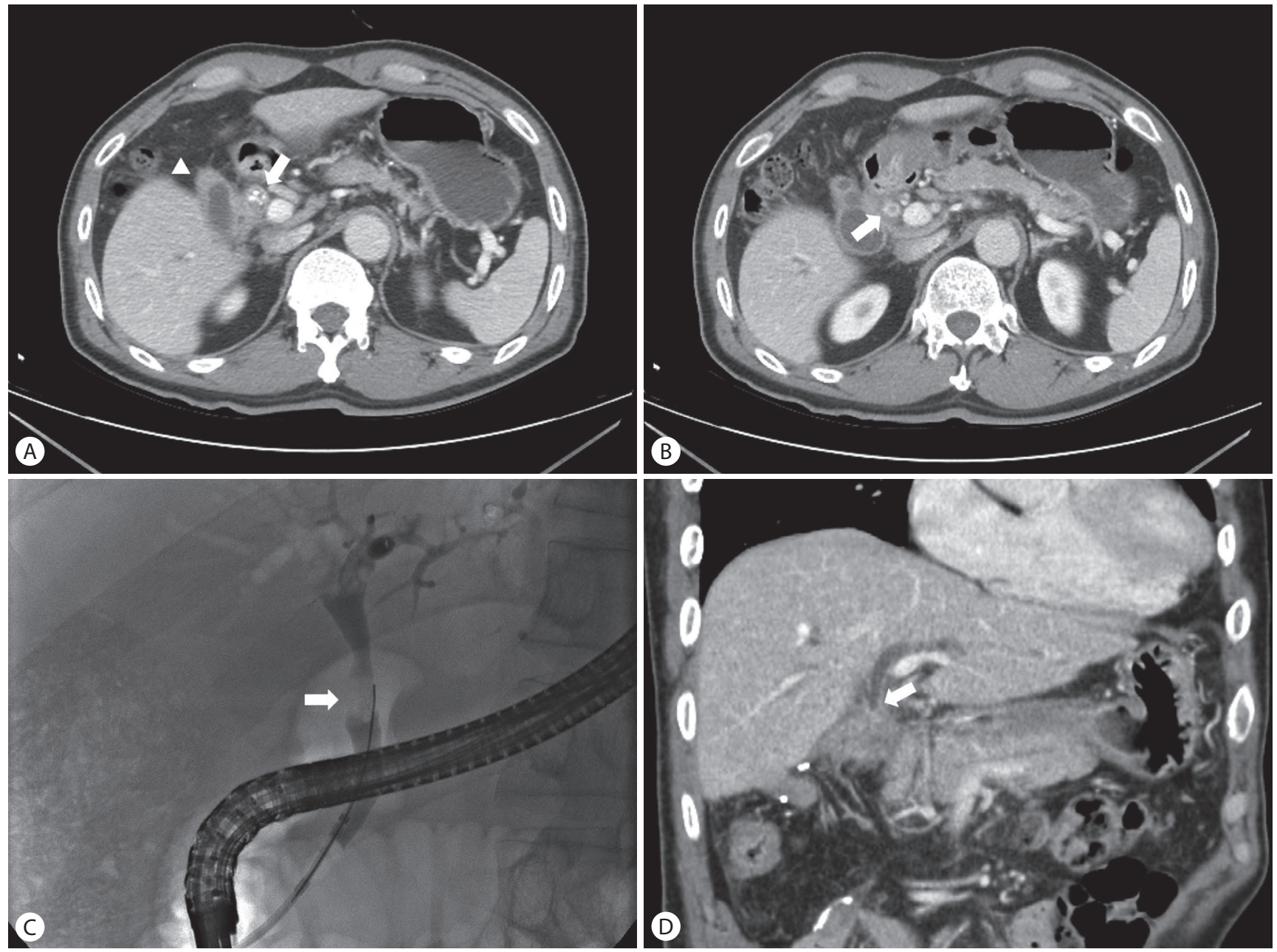

Fig. 1. (A) A contrast enhanced axial abdominal computed tomography (CT) images shows multiple stones in the cystic duct (arrow) and irregular wall thickening of gallbladder (arrowhead). (B) Focal enhancement with thickening of common bile duct is also seen (arrow). (C) Endoscopic retrograde cholangiography demonstrates relatively smooth narrowing of the common hepatic duct (arrow) in combination of dilatation of both intrahepatic bile ducts. Mirizzi syndrome was suspected, but malignancy could not be ruled out. (D) After 3 months of Roux-en-Y choledochojejunostomy, a follow-up CT image shows abrupt narrowing of the bile duct at the anastomosis site (arrow) accompanied with upstream bile duct dilatation due to biliary anastomotic stricture. 
common hepatic duct combined with dilation of both IHDs, probably due to impacted stones in the cystic duct (Fig. 1C). Based on these findings, MS (type I) was suspected. However, possibility of cystic duct cancer invading the CBD was also suggested on preoperative diagnosis.

Severe inflammation, adhesion, and fibrosis around GB and CBD were seen during the surgery. Cholecystectomy and isolation of CBD were performed and the result of frozen biopsy was acute and chronic inflammation without evidence of malignancy. Roux-en-Y choledochojejunostomy was done and no definite evidence of immediate postoperative complication was detected.

A postoperative follow-up CT was checked after 3 weeks and it demonstrated mild dilatation of IHDs probably due to benign stricture at the choledochojejunostomy site (Fig. 1D), and total bilirubin level was slightly more elevated than 2 weeks prior $(0.9 \rightarrow 1.2 \mathrm{mg} / \mathrm{dL})$. Therefore, PTBD was consulted to an interventional radiologist. An 8.5-Fr drainage catheter (Cook Medical, Bloomington, IN, USA) was inserted under ultrasonography and fluoroscopy guidance. A tip of the catheter was located in the jejunum and multiple side holes were made for efficient biliary drainage. Four days later, narrowed anastomosis site was dilated using an $8 \mathrm{~mm}$ diameter balloon (Boston Scientific, Marlborough, MA, USA), and the catheter was exchanged into 14-Fr one (Fig. 2A). The drainage tube was clamped to maintain internal drainage of bile, and it was changed in every 3 months to prevent obstruction by bile sludge or stones. On a follow-up cholangiography after 10 months of PTBD, residual stenosis was not observed and free passage of contrast media across the stricture site was seen. We confirmed the patency of the biliary tract and the drainage tube was removed. One month later, no evidence of bile duct dilatation and cholangitis was seen on abdominal CT images (Fig. 2B), and the level of total bilirubin was within normal range $(1.2 \mathrm{mg} / \mathrm{dL})$.

\section{DISCUSSION}

Up to date, several classifications have been suggested for MS and recently suggested classification by Csendes et al. categorized MS into 5 types. Different surgical approach should be planned considering the type of MS, and more complex procedure is required in type II-V patients, such as cholecystectomy and Roux-en-Y hepaticojejunostomy. ${ }^{5} \mathrm{~A}$ precise preoperative diagnosis is important, but it is often challenging to evaluate the presence of fistula or possibility of malignancy, due to severe inflammation and adhesion in MS. For this complexity of the surgical procedure and diffi-
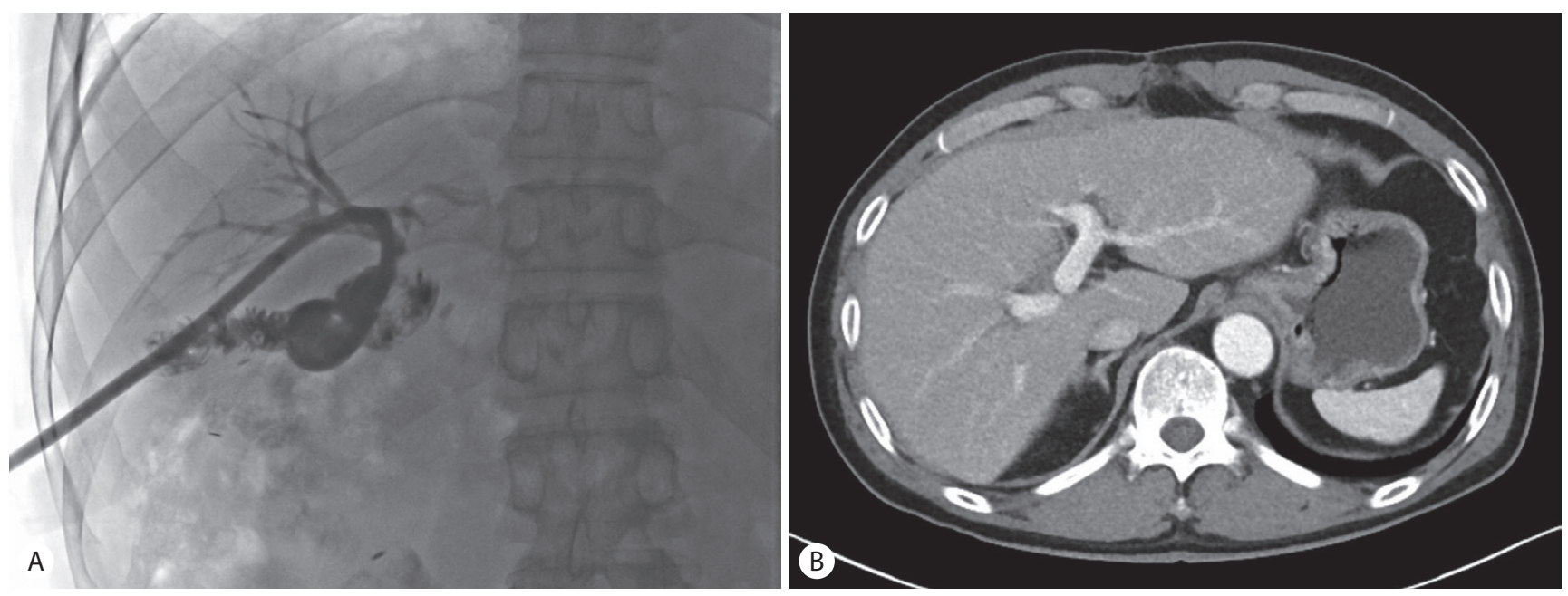

Fig. 2. (A) After balloon dilatation at the stricture area, a 14-Fr drainage catheter was inserted across the anastomosis site. Multiple side holes were made for efficient internal drainage of both intrahepatic bile ducts (IHDs), and catheter was exchanged in every 3 months. (B) The pigtail catheter was removed after 10 months. Dilatation of IHDs was not detected on a follow-up computed tomography image and level of total bilirubin was within normal range. 
culty of preoperative diagnosis, postoperative complications, such as bile duct injury or bile leakage were often reported by several investigators. ${ }^{6,7}$

Benign biliary stricture after bilioenteric anastomosis is a rare complication, and it may occur as anastomotic stricture after surgical repair of bile duct, stricture secondary to intraoperative damage, or result of postoperative inflammation. ${ }^{8}$ Various clinical signs can be presented in patients with biliary stricture, for instance, abnormal liver function tests, obstructive jaundice, or cholangitis. Generally, benign biliary stricture can be initially managed by endoscopic treatment. However, endoscopic approach is not possible for patients who have undergone bilioenteric anastomosis. For these patients, percutaneous treatments have been widely performed with long-term biliary drainage, balloon dilatation or stent placement at the stricture site. ${ }^{9-11}$

In terms of PTBD, once a guide wire is crossed the stenotic lesion, drainage catheter is inserted across the stricture site for internal bile drainage. It will be exchanged gradually to a larger diameter to dilate the tract slowly and will be maintained for 6 months or more. Although keeping a longterm drainage catheter would have increased risk of infection, and quality of life of the patient with this process might be low, there are some advantages of PTBD compared with other percutaneous procedures. Balloon dilatation can be performed along the PTBD tract at the same time, and a drainage tube can be easily removed or exchanged compared to a stent insertion at the stricture site. Therefore, long-term PTBD is commonly accepted in the treatment of benign biliary strictures which are unable to be managed with endoscopic approach, especially in patients with bile duct stricture following liver transplantation. ${ }^{12}$ As our patient underwent Roux-en-Y choledochojejunostomy and cholecystectomy due to severe inflammation and adhesion with suspicion for malignancy, the optimal treatment of postoperative biliary stricture at the anastomosis site was a percutaneous approach.

In conclusion, we experienced a case of postoperative biliary anastomotic stricture in patient with MS that was successfully treated by long-term PTBD. Percutaneous manage- ment of benign biliary stricture can be a treatment of choice in case of bilioenteric anastomosis.

\section{요 약}

미리찌 증후군은 담낭결석증의 드문 합병증으로, 담낭 경부나 담낭관의 결석에 의한 압박으로 인해 총간관의 폐쇄가 발생하게 된다. 미리찌 증후군은 수술적 치료를 하게 되며 그 방법은 질환의 세부 분류에 따라 다양하다. 미리찌 증후군의 외과적 치료 후 발생한 담관 협착은 드문 합병증이며 담도-장 문합술을 시행한 환자에서 이를 내시경적으로 치료하는 것은 불가능하다. 본 증례는 미리찌 증후군의 수술적 치료 후 발생한 담관 문합부 협착을 장기간 경피경간 담도배액술로 치료하여 이를 문헌고찰과 함께 보고하는 바이다.

국문 색인: 미리찌 증후군, 담낭절제술, 총담관조루술, 수술 후합병증, 인터벤션영상의학

\section{Conflicts of Interest}

The authors have no conflicts to disclose.

\section{REFERENCES}

1. Csendes A, Díaz JC, Burdiles P, Maluenda F, Nava O. Mirizzi syndrome and cholecystobiliary fistula: a unifying classification. Br J Surg 1989:76:1139-1143.

2. Schäfer M, Schneiter R, Krähenbühl L. Incidence and management of Mirizzi syndrome during laparoscopic cholecystectomy. Surg Endosc 2003;17:1186-1190; discussion 1191-1192.

3. Beltran MA, Csendes A, Cruces KS. The relationship of Mirizzi syndrome and cholecystoenteric fistula: validation of a modified classification. World J Surg 2008;32:2237-2243.

4. Chen $H$, Siwo EA, Khu M, Tian Y. Current trends in the management of Mirizzi syndrome: a review of literature. Medicine (Baltimore) 2018;97:e9691.

5. Beltran MA. Mirizzi syndrome: history, current knowledge and proposal of a simplified classification. World J Gastroenterol 2012;18:4639-4650.

6. Aydin U, Yazici P, Ozsan I, et al. Surgical management of Mirizzi syndrome. Turk J Gastroenterol 2008;19:258-263.

7. Antoniou SA, Antoniou GA, Makridis C. Laparoscopic treatment of Mirizzi syndrome: a systematic review. Surg Endosc 2010;24:33-39.

8. Krokidis M, Orgera G, Rossi M, Matteoli M, Hatzidakis A. Interventional radiology in the management of benign biliary stenoses, biliary 
leaks and fistulas: a pictorial review. Insights Imaging 2013;4:77-84.

9. Weber $A$, Rosca B, Neu B, et al. Long-term follow-up of percutaneous transhepatic biliary drainage (PTBD) in patients with benign bilioenterostomy stricture. Endoscopy 2009;41:323-328.

10. Ko GY, Sung KB, Yoon HK, Kim KR, Gwon DI, Lee SG. Percutaneous transhepatic treatment of hepaticojejunal anastomotic biliary strictures after living donor liver transplantation. Liver Transpl 2008;14:1323-1332.
11. Vellody R, Willatt JM, Arabi M, Cwikiel WB. Temporary placement of stent grafts in postsurgical benign biliary strictures: a single center experience. Korean J Radiol 2011;12:708-713.

12. Imamine $R$, Shibata $T$, Yabuta M, et al. Long-term outcome of percutaneous biliary interventions for biliary anastomotic stricture in pediatric patients after living donor liver transplantation with Roux-en-Y hepaticojejunostomy. J Vasc Interv Radiol 2015;26:1852-1859. 